\title{
Anne Bebek Çiftinin Taburcu Edilme Zamanının Bilirubin Düzeyleri Üzerine Etkisi
}

\author{
Derya Girgin ${ }^{1}$, Ali Bülbül ${ }^{1}$, Sinan Uslư ${ }^{1}$, Umut Zübarioğlu' ${ }^{1}$, Mesut Dursun ${ }^{1}$, Evrim Kıray Başs ${ }^{1}$ Selda Arslan ${ }^{1}$
}

\begin{abstract}
ÖZET:
Anne bebek çiftinin taburcu edilme zamanının bilirubin düzeyleri üzerine etkisi

Amaç: Gebelik haftası $\geq 35$ hafta olan bebeklerde taburcu edilme zamanının hiperbilirubinemi nedeniyle yeniden hastaneye yatış üzerine etkisini araştırmak.

Gereç ve Yöntem: Hastanemiz Yenidoğan Kliniğinde, Ocak 2010 - Haziran 2011 tarihleri arasında, gebelik süresi $\geq 35$ hafta olan ve sarılık nedeniyle yatırılarak tedavi edilen tüm bebekler çalışmaya alındı. Hastalarda sarılığın etiyolojisi, kliniği, laboratuvar özellikleri ve uygulanan tedaviler kaydedildi. Anne bebek çiftinin taburcu edilme zamanı ile bilirubin değerleri karşılaştıııldı.

Bulgular: Çalışma süresince kriterlere uyan 222 bebek değerlendirildi. Hiperbilirubinemi etyolojisi incelemesinde en sık saptanan nedenler; ABO uyuşmazlığı 66 (\%29,7), Rh uyuşmazlığı $19(\% 8,6)$ ve patolojik oranda tartı kaybı $19(\% 8,5)$ olarak sıralandı. Bebeklerin 90 'ında $(\% 40,6)$ herhangi bir etyolojik neden bulunamadı. Patolojik tartı kaybının total serum bilirubin (TSB) üzerine anlamlı etkisi olduğu bulundu ( $p: 0,014)$. ABO uygunsuzluğu ve TSB değerleri arasında anlamlı negatif korelasyon saptandı $(p<0,001)$, bununla birlikte $A B O$ uygunsuzluğu olan bebeklerin getiriliş günlerinin anlamlı olarak daha kısa olduğu bulundu $(p<0,001)$. Taburculuk öncesi sarılığı olan bebeklerin hastaneye geliş günlerinin anlamlı olarak daha kısa olduğu $(p<0,001)$ ve TSB değerlerinin anlamlı olarak daha düşük olduğu saptandı $(p<0,001)$. Doğum sonrası

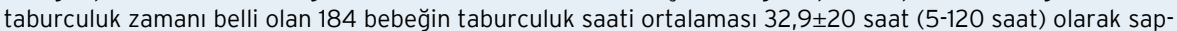
tandı. Doğum sonrası hastaneden taburculuk saatinin TSB değerlerine anlamlı etkisi saptanmadı. Ortalama taburculuk süresi hastanemizde, diğer devlet hastanelerinde ve özel hastanelerde sırasıyla $37,7 \pm 22$ saat, $34,6 \pm 19,8$ saat ve $25,1 \pm 14,7$ saat idi. Ortalama kontrole çağrılma zamanı hastanemizde, diğer devlet hastanelerinde ve özel hastanelerde sırasıyla $4 \pm 2,1$ gün, $5 \pm 3,2$ gün ve $5,3 \pm 3,6$ gün saptandı. Hastanemizde doğan bebeklerin doğum sonrası taburculuk saatlerinin özel hastanede doğan bebeklere göre anlamlı olarak uzun olduğu (p:0,001) ve hastanemizde doğan bebeklerin kontrole çağırılma günlerinin özel hastanede doğanlara göre anlamlı olarak kısa olduğu saptandı (p:0,019).

Sonuç: Çalışmamızda doğum sonrası taburculuk saatinin geliş hiperbilirubinemi düzeyi üzerine olumsuz bir etkisi saptanmadı. Patolojik tartı kaybı ve ABO uygunsuzluğunun hiperbilirubinemi gelişimi için risk faktörleri olduğu belirlendi. Hastanemizde, özel hastanelere göre taburcu edilme zamanının daha geç ve kontrole çağrııma zamanının daha erken olduğu belirlendi.

Anahtar kelimeler: Yenidoğan, taburcu edilme zamanı, bilirubin düzeyleri
\end{abstract}

ABSTRACT:

The effect of postpartum discarge timing of mother-baby couple on bilirubin levels

Objective: The purpose of the study is to investigate the effect of discharge time on rehospitalisation of babies with gestational age $\geq 35$ weeks from hyperbilirubinemia.

Material and Method: Between January 2010 to June 2011, all babies included to study who were $\geq 35$ weeks and treated for hyperbilirubinemia in our newborn clinic. Etiology, clinical and laboratory features and given therapies were recorded. Bilirubin levels compared according to postpartum discarge time of mother-baby couple.

Results: Two hundred and twenty two babies who met criteria were assessed. Mostly detected reasons during hyperbilirubinemia etiology investigations were; $A B O$ incompatibility in 66 babies (29,7\%), Rh incompatibility in 19 babies $(8,6 \%)$ and pathologic weight loss in 19 babies $(8,5 \%)$. There were no etiologic reason found in $90(40,6 \%)$ babies. It was detected that pathologic weight loss had significant effect on total serum bilirubin (TSB) levels $(p=0,014)$. Negative correlation between ABO incompatibility and TSB levels was detected $(p<0,001)$, but babies with $A B O$ incompatibility had significantly shorter duration of hospital admission $(p<0,001)$. Mean discharge time of 184 babies who had known postnatal discharge time was detected as $32,9 \pm 20$ hours (5-120 hours). There was no significant effect of postnatal discharge time detected on TSB levels. Mean discharge times at our hospital, state hospital and special hospital were found $37,7 \pm 22$ hours, $34,6 \pm 19,8$ hours and $25,1 \pm 14,7$ hours, respectively. The follow up examination time at our hospital, state hospital and special hospital were found $4 \pm 2,1$ days, $5 \pm 3,2$ days and $5,3 \pm 3,6$ days, respectively. Babies born in our hospital had significantly longer postnatal discharge time (p.0,001) and shorter duration for follow up examination $(\mathrm{p}: 0,019)$ against special hospitals.

Conclusion: In our study, it was detected that postnatal discharge time of mother baby couple had no negative effect on admission bilirubinemia levels. Pathologic weight loss and $A B O$ incompatibility were detected as risk factors for development of hyperbilirubinemia. We found that postnatal discharge time is longer and duration for follow up is shorter in our hospital according to special hospitals.

Key words: Newborn, postdischarge time, bilirubin levels

Ş.E.E.A.H. Tıp Bülteni 2015;49(3):187-94
'Sişli Hamidiye Etfal Eğitim ve Araştırma Hastanesi, Yenidoğan Kliniği, İstanbul - Türkiye

Yazışma Adresi / Address reprint requests to: Ali Bülbül,

Şişli Hamidiye Etfal Eğitim ve Araştırma

Hastanesi, Yenidoğan Kliniği, İstanbul - Türkiye

Telefon / Phone: +90-505-265-4425

E-posta / E-mail:

drbulbul@yahoo.com

Geliş tarihi / Date of receipt:

23 Şubat 2015 / February 23, 2015

Kabul tarihi / Date of acceptance: 1 Nisan 2015 / April 1, 2015 


\section{GíRiş}

Yenidoğan bebeğin ve annesinin doğum sonrası hastanede kalış süreleri; erken problemleri tespit edecek ve ailenin bebeğe evde verecekleri bakıma hazır olduklarını kapsayacak şekilde uzun olmalıdır (1). İntrauterin yaşamdan ekstrauterin yaşama geçişte soruna neden olabilen kardiyopulmoner hastalıklar genellikle doğumdan sonraki ilk 12 saatte bulgu verir (1). Ancak sarılığın gözle görünür hale gelmesi, duktus bağımlı kardiyak lezyonlar, gastrointestinal obstruksiyon ve diğer adaptasyon sorunlarının tespiti için bebeklerin, deneyimli sağlık görevlileri tarafından daha uzun süreli gözlemi gerekmektedir $(1,2)$.

Son 30 yılda komplikasyonsuz doğum sonrasında anne bebek çiftinin hastanede kalış süresi genel hasta bakımındaki iyileşme ve gelişmiş ülkelerde sigorta şirketlerinin belirli bir zamandan sonra sağlık giderlerini ödememe boyutları nedeniyle, kısalmıştır (3). Amerika Birleşik Devletleri'nde postpartum hastanede kalış süresi 1970'lerden 1990'lı yılların ortalarına kadar düzenli olarak azalmıştır. Normal spontan vajinal doğum (NSD) sonrası hastanede kalış süresi 1970'te ortalama 3,9 gün iken, 1993'te 2 güne düşmüştür. Sezaryenle doğumda ise aynı zaman periyodunda bu süre 7,9 günden 3,9 güne gerilemiştir (4). Ülkemizde de genel sağlık hizmeti veren hastanelerdeki hasta yoğunluğu, hastanelerin altyapı yetersizligi ve ekonomik nedenlerle, anne-bebek çifti ya erken ya da çok erken taburcu edilmektedir (3).

Ancak son yıllarda, doğum sonrası hastanede kalış süresi azaldıkça, özellikle taburculuk sonrası sarılık ve dehidratasyonun daha sık saptandığını bildiren yayınlar artmış, erken taburculuğun ne kadar güvenli olduğu sorgulanmaya başlanmıştır (5). Çalışmalarda konu ile ilgili görüş ayrılıkları mevcut olup; bir grup erken taburculuğun faydalarını savunurken, diğer bir grup ise zararlarının daha fazla olabileceğini belirtmektedir. Erken taburculuğun yararları olarak ailenin bebeği kabullenmesi, anne-bebek duygusal birlikteliğinin kuvvetlenmesi, bebeğin hastane infeksiyonlarından korunması, annenin evde daha iyi dinlenmesi ve ailenin ekonomik olarak rahat ettirilmesi sayılmaktadır $(3,6)$.

Diğer yandan, bebeklerin erken taburcu edilmesine karşı olanlar; bebeklerin hastane dışında takibinin zor olacağını ve özellikle birinci günden sonra bulgu veren hastalıkların tanısının gecikeceğini savunmaktadırlar $(3,7)$. Bunların başında yenidoğan döneminde tekrar hastaneye yatışın en sık nedeni olan sarılık gelmektedir $(3,8)$. Çalışmalarda sarılık nedeni ile tekrar hastaneye yatış nedenleri arasında hekim ile anne arasında yeterli iletişim kurulamaması, emzirme konusunda yeterli ve uygun desteğin verilememesi, annenin postpartum birinci günde bilişsel fonksiyonlarında azalma olması ve özellikle kış şartlarında ailelerin bebekleri zamanında kontrole getirememesi gibi faktörlerin önemli olduğu bildirilmektedir $(3,6,8,9)$.

Prospektif olarak planlanan çalışmamızda, birincil olarak hastanemiz yenidoğan ünitesine sarılık nedeni ile yatırılması gereken term ve sınırda preterm bebeklerde sarılık gelişimi ile taburculuk saatleri arasında ilişki olup olmadığının tespiti ve sarılık miktarı ile taburculuk süresi arasında bir sınır değerin belirlenmesi, ikincil olarak ise sarılık nedeni ile yatırılan bu bebeklerde sarılık gelişimine etki eden risk faktörlerinin prospektif olarak tanımlanması amaçlanmıştır.

\section{GEREÇ VE YÖNTEM}

Şişli Hamidiye Etfal Eğitim ve Araştırma Hastanesi, Yenidoğan Kliniğinde, on sekiz aylık süre içerisinde (Ocak 2010-Haziran 2011), gebelik süresi $\geq 35$ hafta arasında olan ve sarılık nedeniyle yatırılarak tedavi edilen tüm bebekler çalışmaya alındı. Bebeklerin yatış esnasında geçmiş bilgileri yazılı kayıtlardan ve anneden alındı. Yatan bebeklerin izlemleri; postnatal hastaneden taburcu edilme saatleri, sarılık etiyoloji ve klinikleri, laboratuvar özellikleri ve uygulanan tedavileri prospektif olarak kaydedildi.

Bebeklerin postnatal hastaneden taburculuk saatleri, taburculuk öncesi sarılık olup olmadığı, ailelerin kontrol gününe uyup uymadıkları, cinsiyetleri, gebelik haftaları, doğum ağırlıkları, başvurudaki ağırlıkla$\mathrm{rl}$, boy ve baş çevreleri, beslenme şekilleri (sadece anne sütü, formüla, karma), doğum şekilleri ve doğum yerleri (hastanemiz, devlet hastaneleri, özel hastaneler, evde doğum), kaçıncı çocuk oldukları, fototerapi almış kardeş hikayeleri, sefal hematom varlığı, sarılığın fark edildiği gün, bebeğin hastaneye getirildiği gün, yattığı gün sayısı, akraba evliliği hika- 
yesi, bilirubin değerleri (total ve direkt bilirubin), venöz hematokrit ve retikülosit düzeyleri, anne ve bebek kan grupları, direkt coombs pozitifliği, idrarda redüktan madde varlığı, TSH (Tiroid stimulan hormon) ve T4 düzeyleri, glukoz 6 fosfat dehidrogenaz düzeyleri, uygulanan fototerapi süresi, kan değişimi uygulaması, sepsis varlığı ve periferik yayma bulguları prospektif olarak kaydedildi. Gebelik yaşı son adet tarihine göre, son adet tarihi bilinmeyen bebeklerde ilk 48 saat içinde başvuranlarda Dubowitz skorlaması kullanılarak, 48 saatten sonra ise klinik muayene bulgularına göre hesaplandı (10). Hiperbilirubinemili hastalarda fototerapi başlama ve kan değişimi kararı Amerikan Pediatri Akademisi'nin önerilerine göre alındı (2).

\section{Çalışmaya Alınmama Kriterleri:}

1. Gebelik süresi $<35$ hafta olan bebekler

2. Majör konjenital anomalisi olan bebekler (diyafragma hernisi, gastroşizis vb.) çalışmaya alınmadı.

\section{Tanımlar}

Erken Taburculuk: Doğumu takiben 48 saat içinde taburcu edilme "erken taburcu olma" olarak tanımlandı.

Çok Erken Taburculuk: Doğumu takiben 24 saat içinde taburcu edilme "çok erken taburcu olma" olarak tanımlandı.

Patolojik Oranda Tartı Kaybı: Doğum ağırlığına göre geliş ağırlığının \%12 ve daha fazlasının kaybı patolojik tartı kaybı olarak tanımlandı. Tartı kaybı oranı (doğum ağırlığı-geliş ağırlığı)/doğum ağırlığı x100 formülü ile hesaplanmıştır.

Klinik Sepsis: hastaneye getirilen bebeklerde, ilk muayenede sepsis kliniği olan (genel durumun iyi olmaması, toksik görünüm olması, ateş, periferik dolaşımı bozukluğu vb. bulguların yanında laboratuvar analizlerinde lökositoz, sola kayma, CRP (C-Reaktif protein) yüksekliği olan bebekler) ve/veya alınan vücut kültürlerinde üreme saptanan bebekler bu gruba alındı.

Anne sütü ile beslenme: Sadece anne sütü ile beslenen grubu temsil eder.
Anne sütüyle birlikte formüla ile beslenme (karma beslenme): Anne sütünün yanında ek olarak formüla alan grubu temsil eder.

\section{İstatistiksel Analiz}

Çalışmada elde edilen bulguların istatistiksel analizi için SPSS (Statistical Package for Social Sciences) for Windows 16.0 programı kullanıldı. Araştırmada demografik özellikler tanımlayıcı istatiksel analizi ile değerlendirildi. Tanımlayıcı istatistik metotları (ortalama, standart sapma, ortanca, alt ve üst sınır) yanı sıra nitel ve nicel verilerin karşılaştırmasında Student't testi, Chi-square ve Fisher's exact testi kullanıldı. Beslenmenin serum bilirubin düzeyleri ve fototerapi sürelerine olan ilişkisi ANOVA testi ile değerlendirildi. Anlamlılık $p<0.05$ düzeyinde değerlendirildi.

\section{BULGULAR}

Demografik özellikler: Çalışmamızda Ocak 2010 - Haziran 2011 tarihleri arasında sarılık nedeni ile hastanemiz yenidoğan ünitesine yatırılan term ve sınırda preterm 222 bebeğin dosyaları prospektif olarak incelendi. Hasta grubumuzun demografik özelliklere ait tanımlayıcı değerler Tablo 1 ve 2 'de sunulmuş̧tur.

Sarılık etiyolojisi: Çalışmaya alınan 222 hastanın etiyolojik değerlendirilmesinde saptanan nedenler Tablo 3'de sunulmuştur.

Kaçıncı çocuk olmanın sarılık üzerine etkisi: Bebeklerin ailenin kaçıncı çocuk olduğu dağılımları ve ortalama TSB (Total Serum Bilirubin) düzeyi ile ilişkileri Tablo 4'te sunuldu. Geliş TSB düzeyi ile kaçıncı çocuk olduğu arasında anlamlı bir fark saptanmadı $(p: 0,2)$.

Tablo 1: Çalışmaya alınan bebeklerin demografik özellikleri

\begin{tabular}{lcc}
\hline (n:222) & Değerler* & Dağılım aralığı \\
\hline Gebelik zamanı, (hafta) & $38,7 \pm 1,2$ & $35-42$ \\
Doğum kilosu, (g) & $3160 \pm 490$ & $1600-4500$ \\
Doğum boyu, (cm) & $48,9 \pm 2,5$ & $41-54$ \\
Baş çevresi, (cm) & $34 \pm 1,4$ & $29-37,5$ \\
Geliş kilosu, (g) & $3040 \pm 480$ & $1520-4200$ \\
Anne yaşı, (yıl) & $27,7 \pm 6$ & $17-45$ \\
\hline *Ortalama standart sapma & &
\end{tabular}


Tablo 2: Çalışmadaki bebeklerin tanımlayıcı değerleri

\begin{tabular}{|c|c|c|c|c|}
\hline & Sayı (n) & $\%$ & Geliş TSB değeri & p \\
\hline \multicolumn{5}{|l|}{ Doğum yeri } \\
\hline Şişli Etfal Hastanesi & 109 & 49,1 & $17,2 \pm 2,8$ & \\
\hline Devlet hastanesi & 40 & 18 & $18,1 \pm 4,3$ & 0,29 \\
\hline Özel Hastane & 70 & 31,5 & $17,4 \pm 3,3$ & \\
\hline Ev & 3 & 1,4 & $18,8 \pm 2,9$ & \\
\hline \multicolumn{5}{|l|}{ Doğum şekli } \\
\hline NSD & 128 & 57,6 & $18 \pm 3,5$ & $\mathrm{p}: 0,92$ \\
\hline Sezaryen & 93 & 41,9 & $17,9 \pm 3,6$ & \\
\hline Vakum & 1 & 0,5 & & \\
\hline \multicolumn{5}{|l|}{ Cinsiyet } \\
\hline Erkek & 134 & 60,4 & $18,3 \pm 3,3$ & $\mathrm{p}: 0,064$ \\
\hline $\mathrm{K} I \mathrm{Z}$ & 88 & 39,6 & $17,4 \pm 3,9$ & \\
\hline \multicolumn{5}{|l|}{ Anne eğitim durumu } \\
\hline Eğitimsiz & 26 & 11,7 & $16,5 \pm 3,8$ & \\
\hline illkokul & 100 & 45 & $18,1 \pm 3,3$ & \\
\hline Ortaokul & 45 & 20,3 & $18,4 \pm 4,3$ & $\mathrm{p}: 0,21$ \\
\hline Lise & 45 & 20,3 & $17,8 \pm 3$ & \\
\hline Üniversite & 6 & 2,7 & $19,2 \pm 3,2$ & \\
\hline \multicolumn{5}{|l|}{ Sigara içen anne } \\
\hline Evet & 29 & 13,1 & $18,8 \pm 3$ & $\mathrm{p}: 0,19$ \\
\hline Hayır & 193 & 86,9 & $17,8 \pm 3,6$ & \\
\hline \multicolumn{5}{|l|}{ Beslenme modeli } \\
\hline Anne Sütü & 175 & 78,8 & $18,1 \pm 3,5$ & $\mathrm{p}: 0,4$ \\
\hline Karma & 47 & 21,2 & $17,6 \pm 3,6$ & \\
\hline \multicolumn{5}{|l|}{ Patolojik tartı kaybı } \\
\hline Var & 19 & 8,5 & $19,9 \pm 3,7$ & $\mathrm{p}: 0,014$ \\
\hline Yok & 203 & 91,5 & $17,8 \pm 3,5$ & \\
\hline
\end{tabular}

NSD: Normal spontan vajinal doğum, TSB:Total serum biluribin

Tablo 3: Bebeklerde sarılık etiyolojisinde saptanan nedenlerin dağılımları

\begin{tabular}{lcc}
\hline Etiyoloji & Sayı (n) & $\%$ \\
\hline ABO uyuşmazlığı & 66 & 29,7 \\
Rh uyuşmazlığı & 19 & 8,6 \\
ABO+Rh uyuşmazlığı & 5 & 2,2 \\
Subgrup+Rh uyuşmazlığı & 1 & 0,45 \\
Klinik sepsis & 3 & 1,3 \\
Patolojik tartı kaybı & 19 & 8,5 \\
Diğer (DAÇ, SGA, Sefal hematom, & 24 & 10,8 \\
Down sendromu) & & \\
Nedeni bulunamayan & 90 & 40,6 \\
\hline
\end{tabular}

G6PD: Glukoz 6 fosfat dehidrogenaz, DAÇ: Diyabetik anne çocuğu, SGA: Gestasyon yaşına göre düşük doğum tartıı

\section{Hastaneye yatışta beslenme şeklinin sarılık üzeri-} ne etkisi: Hastaların $175^{\prime} i(\% 78,8)$ sadece anne sütü, $47^{\prime}$ si $(\% 21,2)$ karma şekilde beslenmekteydi. Sadece formüla ile beslenen bebek yoktu. Hastaların gelişlerindeki beslenme durumlarıyla TSB düzeyleri arasında anlamlı ilişki saptanmadı ( $p: 0,4)$. Beslenme şeklinin TSB düzeyleri ile ilişkisi Tablo 2'de sunuldu.

Patolojik tartı kaybı ve TSB ilişkisi: Tüm grupta patolojik tartı kaybı saptanan bebek sayısı $19(\% 8,5)$ idi. Patolojik tartı kaybı olan ve olmayan iki grubun ortalama TSB düzeyleri arasında anlamlı fark bulundu (p:0,014, ortalama fark 2,1 mg/dl). Patolojik tartı kaybı ve TSB düzeyi ilişkisi Tablo 2'de sunuldu.

Cinsiyetin, doğum şeklinin, anne eğitimi ve sigaranın geliş TSB üzerine etkisi: Cinsiyetin, doğum şeklinin, annenin eğitim durumunun ve annenin gebelikte sigara içme durumunun geliş TSB ile ilişkisi saptanmadı (Tablo 2).

$A B O$ uygunsuzluğu ve $R h$ uygunsuzluğunun TSB ve geliş günü ilişkisi: Tüm grupta $A B O$ uygunsuzluğu ve Rh uygunsuzluğu saptanan bebeklerin dağılımı ve bebeklerin geliş TSB değerleri ile ilişkisi tablo $5^{\prime}$ te sunuldu. ABO uygunsuzluğu olan bebeklerin yatış bilirubin değerlerinin anlamlı olarak daha düşük olduğu belirlendi.

Postnatal taburculuk öncesi sarılık varlığı, TSB ve getiriliş günü ilişkisi: Tüm grupta postnatal hastaneden taburculuk öncesi sarılığı saptanan bebek sayısı $67(\% 30,1)$ ve taburculuk öncesi sarılığı olmayan bebek sayısı $155(\% 69,9)$ idi. Taburculuk öncesi sarıIığın fark edilme durumunun kontrole gelme zamanı, 
Tablo 4: Bebeğin ailenin kaçıncı çocuk olma özelliği ile geliş TSB düzeyleri arasındaki ilişki

\begin{tabular}{lccc}
\hline Kaçıncı çocuk olma & Hasta sayısı $(\mathbf{n})$ & \% & TSB düzeyi* (mg/dl) \\
\hline 1. & 103 & 46,3 & 18,4 \\
2. & 67 & 30,1 & 17,8 \\
3. & 33 & 14,8 & 17,2 \\
4. & 15 & 6,7 & 18,1 \\
5. ve üstü & 4 & 1,8 & 15,1 \\
\hline
\end{tabular}

*Ortalama \pm standart sapma, TSB:Total serum biluribin

Tablo 5: ABO uygunsuzluğu ve Rh uygunsuzluğunun TSB ile ilişkisi

\begin{tabular}{lccc}
\hline & Hasta sayısı (\%) & TSB düzeyi (mg/d)* & p \\
\hline ABO uygunsuzluğu var & 29,7 & $16,3 \pm 4,4$ & $<0,001$ \\
ABO uygunsuzluğu yok & 70,3 & $18,7 \pm 2,8$ & 0,43 \\
Rh uygunsuzluğu var & 8,5 & $17,3 \pm 4$ & $18 \pm 3,5$ \\
Rh uygunsuzluğu yok & 91,5 & & \\
\hline
\end{tabular}

*Ortalama \pm sandart sapma, TSB: Total serum biluribin

Tablo 6: Taburculuk öncesi sarılık varlı̆ı̆ının getiriliş günü, TSB düzeyleri ve fototerapi süresi ile ilişkisi

\begin{tabular}{lccccc}
\hline $\begin{array}{l}\text { Taburculuk } \\
\text { öncesi sarılık }\end{array}$ & $\begin{array}{c}\text { Getiriliş zamanı } \\
\text { (gün)* }\end{array}$ & $\mathbf{p}$ & $\begin{array}{c}\text { TSB düzeyi } \\
\text { (mg/d)* }\end{array}$ & p & $\begin{array}{c}\text { Fototerapi süresi } \\
\text { ( saat)* }\end{array}$ \\
\hline Var & $3,1 \pm 2$ & $<0,001$ & $15,7 \pm 4,1$ & $<0,001$ & $42,5 \pm 23,1$ \\
Yok & $5,3 \pm 2,6$ & & $18,9 \pm 2,8$ & $39,2 \pm 15,2$ & 0,2 \\
\hline
\end{tabular}

*Ortalama \pm standart sapma, TSB: Total serum biluribin

geliş TSB düzeyi ve fototerapi süresi ile ilişkisi tablo $6^{\prime}$ da sunuldu. Hastaneden taburculuk öncesi sarılığı saptanmayan bebeklerin, sarılığı saptanan bebeklere göre TSB değerleri anlamlı olarak daha yüksek olduğu ve kontrole getiriliş zamanlarının daha uzun olduğu saptanırken bu bebeklerin fototerapi alma süreleri açısından bir fak saptanmadı (Tablo 6).

Doğum sonrası taburculuk ve kontrol:

Çalışmamızı oluşturan 222 hastadan 35'inde sarılık anne yanında fark edilip, hastalar doğrudan servise alındı ̆̆ı ve 3 hastada ise evde doğum gerçekleştiği için; bu bebekler doğum sonrası taburculuk ve kontrole gelme zamanı değerlendirmesine alınmadı. Geri kalan 184 hastanın doğum sonrası hastaneden taburculuk saati ortalaması $32,9 \pm 20,1$ saat (5-120 saat) olarak saptandı. Bu 184 bebekten 76'sı $(\% 41,3)$ postnatal ilk 24 saatte, $78^{\prime} i$ ( $\% 42,3^{\prime}$ ü) postnatal 24-48 saatte, 18'i $(\% 9,7)$ postnatal $48-72$ saatte ve $12^{\prime}$ si $(\% 6,5)$ postnatal ilk 72 saatten sonra taburcu edilmişti. Postnatal taburcu edilme süreleri ile hastanede kalış süresi ve fototerapi süreleri arasında anlamlı bir ilişki saptanmadı (Tablo 7). Hastaların geliş TSB düzeyleri ile postnatal taburcu edilme süreleri arasında anlamlı bir fark yoktu (p:0,6) (Tablo 7).

Hastaların kontrole çağırılma günü ortalaması 4,6 2, 6 gün (3-30 gün) iken, kontrole getirilme günleri ortalaması 4,8 2 2,5 gün (2-20 gün) idi. Hastaların 51'inin (\%23) kontrole çağırıldığı güne uymadığı belirlendi. Hastanemizde, devlet hastanelerinde ve özel hastanelerde doğan bebeklerin doğum sonrası taburculuk zamanı, kontrole çağırılma zamanı ve kontrole uyum oranları Tablo 8'de sunuldu.

Taburcu edilme süresi açısından hastanemizde doğan bebekler ile özel hastanelerde doğan bebekler arasında anlamlı fark olduğu belirlendi ( $p: 0,001$, ortalama fark 12,6 saat). Doğum yerlerine göre kontrole çağırılma günü ortalamasında anlamlı bir fark saptandı (p:0,019). Hastanemizde doğan bebekler ile özel hastanelerde doğan bebeklerin kontrole çağrılma süresi arasında anlamlı fark vardı (p:0,016, ortalama fark 1,2 gün). Hastanemizde doğan 90 hastanın 65'i (\%72,2), diğer devlet hastanelerinde doğan 31 hastanın 20'si $(\% 64,5)$, özel hastanelerde doğan 63 hastanın 50'si $(\% 79,3)$ kontrole çağırıldığı güne uymuştu (Tablo 8). 
Tablo 7: Postnatal taburculuk saatlerinin TSB, fototerapi süresi ve hastanede yatış süresine etkisi (184 bebek için)

\begin{tabular}{lccccc}
\hline $\begin{array}{l}\text { Hastaneden taburcu } \\
\text { edilme zamanı } \\
\text { (saat) }\end{array}$ & $\begin{array}{c}\text { TSB düzeyi } \\
\text { (mg/d)* }\end{array}$ & $\mathbf{p}$ & $\begin{array}{c}\text { Fototerapi süresi } \\
\text { (saat)* }\end{array}$ & p & $\begin{array}{c}\text { Hastanede kalış süresi } \\
\text { (gün)* }\end{array}$ \\
\hline Ilk 24 saat & $19,1 \pm 3$ & & $39,3 \pm 16,4$ & & $2,8 \pm 1,3$ \\
24-48 saat & $18,6 \pm 2,8$ & & $40,6 \pm 14,6$ & & $3 \pm 1,5$ \\
48-72 saat & $18,3 \pm 2,2$ & 0,6 & $33,1 \pm 14,6$ & 0,28 & $2,4 \pm 0,7$ \\
>72 saat & $19 \pm 2,4$ & & $37,1 \pm 11,8$ & & $2,4 \pm 0,5$ \\
\hline
\end{tabular}

*Ortalama \pm standart sapma, TSB: Total serum biluribin

Tablo 8: Hastanelere göre bebeklerin doğum sonrası taburculuk zamanı, kontrole çağırılma zamanı ve kontrole uyum oranlarının karşılaştırılması

\begin{tabular}{|c|c|c|c|c|c|}
\hline Doğum yeri & $\begin{array}{c}\text { Hastaneden } \\
\text { taburculuk zamanı } \\
\text { (saat)* }\end{array}$ & $\mathbf{p}$ & $\begin{array}{c}\text { Kontrole } \\
\text { çağırılma zamanı } \\
\text { (gün)* }\end{array}$ & p & $\begin{array}{l}\text { Kontrole çağırılma } \\
\text { zamanına uyum (\%) }\end{array}$ \\
\hline Şişli Hamidiye Etfal EAH & $37,7 \pm 22$ & 0,001 & $4 \pm 2,1$ & 0,019 & 72,2 \\
\hline Devlet hastaneleri & $34,6 \pm 19,8$ & & $5 \pm 3,2$ & & 64,5 \\
\hline Özel hastaneler & $25,1 \pm 14,7$ & & $5,3 \pm 3,6$ & & 79,3 \\
\hline
\end{tabular}

\section{TARTIŞMA}

Sağlıklı term yenidoğan bebeğin postpartum hastanede kalış süresini belirlemede her anne-bebek çifti için bireysel özellikler göz önüne alınarak karar verilmesi gerekmektedir (11). Günümüzde çeşitli nedenlerle erken taburcu edilen bebeklerin hastaneye tekrar yatış sebepleri ile ilgili çalışmaların giderek artış gösterdiği saptanmaktadır. Literatürde erken taburculuğun faydaları olarak; ailenin bebeği kabullenmesi, anne-bebek duygusal birlikteliğinin kuvvetlenmesi, bebeğin hastane enfeksiyonlarından korunması, annenin evde daha iyi dinlenmesi ve ailenin ekonomik olarak rahat ettirilmesi sayılmaktadır $(3,6)$. Bununla birlikte bebeklerin hastane dışında takibinin zor olacağını ve özellikle birinci günden sonra bulgu veren hastalıkların tanısının gecikeceğini belirterek erken taburculuğun zararlarına odaklanan ciddi yayınlar da bulunmaktadır $(3,7)$. Çalışmalarda, erken taburcu edilen bebeklerde hastaneye tekrar yatışların en sık sebebini hiperbilirubinemi oluşturmaktadır $(3,8,9)$.

Yapılan çalışmaların bir kısmı doğum sonrası erken ve çok erken taburculuğun sarılık nedeniyle yeniden yatış riskini anlamlı olarak arttırdı̆̆ını bildirilmiştir $(9,12)$. Ancak diğer çalışmalarda doğum son- rası erken ve çok erken taburculuğun sarılık nedeniyle yeniden yatış oranına anlamlı bir etkisi olmadığı görülmüştür $(3,13)$. Bizim çalışmamızda postnatal taburculuk saatlerinin (ilk 24 saat, 24-48 saat, 48-72 saat, 72 saatten sonra) geliş TSB üzerine anlamlı etkisi olmadığı saptandı. Uygulanan fototerapi süresinin ve hastanede kalış süresi de postnatal taburculuk saatinden etkilenmediği belirlendi. Ailelerin büyük çoğunluğu (\%77'si) postnatal taburculuk sonrası kontrole çağırıldıkları güne uyarak bebeklerini hastaneye getirmişlerdi. Çalışmamızdaki postnatal taburculuk süresinin geliş TSB değerlerine anlamlı etkisinin olmayışı, bize bu durumun özellikle postnatal taburculuk sonrası izlem programına ailelerin uyumunun yüksek olması ile ilişkili olduğunu düşündürdü. Çalışmamızda bebeklerin doğum yerleri (hastanemiz, diğer devlet hastaneleri ve özel hastaneler) karşılaştırıldığında hastanemizde doğan bebeklerin özel hastanede doğan bebeklere göre postnatal hastaneden taburculuk saatlerinin anlamlı olarak daha uzun olduğu ve postnatal kontrole çağırılma günlerinin anlamlı olarak daha kısa olduğu saptandı. Özetle hastanemizde doğan bebeklerin hastaneden daha geç sürede taburcu edilmekte ve daha erken kontrole çağrılmakta olduğu belirlendi.

Yenidoğan sarılığının erkek bebeklerde daha sık 
görüldüğü bilinmektedir $(2,6,8)$. Çalışmamızda yenidoğan sarılığı nedeniyle takip edilen 222 bebeğin cinsiyet durumu değerlendirildiğinde Erkek/kız oranı 1,5 olarak bulundu. Sarılık ile ilgili yapılan çalışmalarda erkek/kız oranı 1-1,5 arasında değişen sıklıklarda bildirilmiştir (14). Sonucumuz bildirilen oranlar ile uyumlu idi. Chou ve arkadaşlarının yaptıkları çalışmada erkek cinsiyetin yüksek bilirubin düzeyleri için bir risk etmeni olmadı̆̆ bildirilmiştir (15). Çalışmamızda cinsiyetin hiperbiliruineminin şiddeti ile ilişkisi araştırıldığında cinsiyet ile yüksek bilirubin değerleri arasında anlamlı bir fark olmadığ gözlendi.

Literatürde hiperbilirubineminin ilk bebekte daha sık görüldüğü bildirilmektedir $(6,8,16)$. Benzer olarak çalışmamızda ilk bebek olma sıklığı \%46,3 ile en yüksek oranda bulundu. Bolat ve arkadaşlarının yaptığı çalışmada ilk bebek olmanın TSB düzeyleri ile ilişkili olmadığı bildirilmiştir (6). Benzer olarak çalışmamızda da ilk bebek olmanın TSB değerlerini anlamlı olarak arttırmadığı bulundu.

Anne sütü ile beslenmenin hiperbilirubinemi için risk faktörü olduğu bilinmektedir. Ciddi hiperbilirubinemisi olan hastalarda anne sütü ile beslenme oranını \%58-81,4 olarak bildirilmektedir $(15,17)$. Çalışma grubumuzda sadece anne sütü ile beslenen bebekler \%78,8 ve karma beslenen bebekler \%21,2 oranındaydı. Sadece formüla ile beslenen bebek yoktu. Tüm çalışma grubunda beslenme şekliye TSB değerleri karşılaştırıldı̆̆ında beslenme şekli ile TSB değerleri arasında anlamlı ilişki bulunmadı.

Patolojik tartı kaybının hiperbilirubinemi ile ilişkisi birçok çalışmada gösterilmiştir. Patolojik oranda tartı kaybı, bebeğin yetersiz beslendiğini ve enterohepatik bilirubin döngüsünün arttığını dolaylı olarak gösterir. Bu yüzden bebeklerin sık aralıklarla emzirilmesi, günlük sıvı ve kalori ihtiyaçlarının yeterli oranda sağlanması önerilmektedir. Maisels ve arkadaşlarının çalışmasında sarılıklı bebeklerin kilo kaybı, sarılığı olmayan kontrol grubundaki bebeklere göre anlamlı olarak yüksek bulunmuştur (9). Bolat ve arkadaşlarının yaptığı çalışmada, sarılıklı bebeklerin \%13,3'ünde ise patolojik oranda tartı kaybı saptandı$\breve{g}$ ı ve yalnızca anne sütü ile beslenen ve patolojik oranda tartı kaybı olan bebeklerde TSB düzeyinin daha yüksek olduğunu bildirmiştir (6). Çalışmamızda tüm bebeklerde patolojik tartı kaybı oranı \%8,5 iken patolojik tartı kaybı olan bebeklerin TSB düzeyinin tartı kaybı olmayanlara göre daha yüksek olması bu bilgiyi destekliyordu. Doğumdan sonra ilk saatler içinde bebeklerin emmeye teşvik edilmesi, annelere doğumdan sonra belli bir protokol çerçevesinde emzirme eğitimi verilmesi, bebeklerin günlük tartılması ile patolojik tartı kaybına bağlı hiperbilirubinemi tanısı ile hastaneye yatışların azaltılabileceği düşüncesindeyiz.

Doğum şekli ile hiperbilirubinemi riskinin araştırıldığı çalışmalarda, vakum ile doğumun ciddi hiperbilirubinemi gelişiminde bir risk etmeni olduğu bildirilirken, sezaryen ile doğan bebeklerde sarılık gelişme riskinin daha düşük olduğu bildirilmiştir $(18,19)$. Çalışmamızda NSD ile doğum \%57,6, sezaryen ile doğum \%41,9 ve vakum yardımı doğum \%0,5 idi. Bu üç grubun TSB düzeyleri arasında anlamlı fark bulunmadı. Vakum yardımı ile doğumun bizim çalışmamızda TSB düzeylerine etkisiz bulunmasının nedenini, çalışma grubumuzda sadece bir bebeğin vakum yardımıyla doğan bebek olmasına bağladık.

Yenidoğan döneminde gelişen hiperbilirubinemiye yönelik yapılan etiyolojik incelemelerde; en sık ABO uyuşmazlığı (\%20-31,6), Rh uyuşmazlığı (\%810), G6PD (Glikoz 6 Fosfat Dehidrogenaz) eksikliği (\%0,5-21), idrar yolu enfeksiyonu (\%1-8), herediter sferositoz (\%7-8), sepsis (\%1) ve hipotiroidi (\%1-6) saptanmaktadır $(20,21,22)$. Çalışmamızda en sık sebep \%29,7 oranıyla ABO uyuşmazlığı idi. Çalışmamızda $A B O$ uygunsuzluğu olan bebeklerin TSB düzeyleri, $\mathrm{ABO}$ uygunsuzluğu olmayan bebeklerin TSB düzeylerine göre anlamlı olarak düşük bulundu. Biz bu durumu çalışmamızda $\mathrm{ABO}$ uygunsuzluğu olan bebeklerin hastaneye geliş günlerinin, $\mathrm{ABO}$ uygunsuzluğu olmayan bebeklere göre anlamlı olarak kısa bulunmasına bağlamaktayız. Bu durum bize çalışmamızdaki $\mathrm{ABO}$ uygunsuzluğu olan bebeklerin önceden saptanıp erken kontrole çağırıldığını ve postnatal kontrollerinin uygun izlem protokolleri ile yapıldığını göstermektedir.

Taburculuk öncesi hazırlığın önemli bir bölümünü bebeğin sarılık açısından değerlendirilmesi oluşturur. Maisels ve arkadaşlarının yaptı̆̆ı çalışmada taburculuk öncesi sarılık varlığının erken taburcu edilen bebeklerin sarılık nedeniyle yeniden hastane- 
ye yatırılmasında önemli bir risk faktörü olduğu bildirilmektedir (9). Çalışma grubumuzda postnatal taburculuk öncesi sarılık varlığı \%30,1 idi. Postnatal taburculuk öncesi sarılık saptanan bebeklerin TSB değerleri, postnatal taburculuk öncesi sarılığı olmayan bebeklerin TSB düzeylerine göre anlamlı olarak düşük bulundu. Biz bu durumu postnatal taburculuk öncesi sarılık saptanan bebeklerin hastaneye geliş günlerinin, postnatal taburculuk öncesi sarılık saptanmayan bebeklerin hastaneye geliş günlerine göre anlamlı olarak kısa bulunmasına bağlamaktayız. Bu durum çalışma grubumuzdaki bebeklerin postnatal taburculuk öncesi iyi takip edildiğini ve sarılık sapta-

\section{KAYNAKLAR}

1. American Academy of Pediartrics Practice Guideline. Committee on Fetus and Newborn. Hospital stay for healty term newborns. Pediatrics 2010; 125: 405-9.

2. American Academy of Pediartrics, Management of Hyperbilirubinemia in the Newborn infant 35 or more weeks of gestation. Clinical Pratice Guideline. Subcommittee on Hyperbilirubinemia. Pediatrics 2004; 114: 297-316.

3. Akın MA, Kavuncuoğlu S. Erken taburcu olan yenidoğanlarda yeniden hastaneye yatış nedenleri ve sonuçları. Türk Pediatri Arşivi 2006; 41: 201-7.

4. Danielsen B, Castles AG, Damberg CL, Gould JB. Newborn discharge timing and readmissions: California, 1992-1995. Pediatrics 2000; 106: 31-9.

5. Radmacher P, Massey $C$, Adamkin D. Hidden morbidity with "successfull" early discharge. Journal of Perinatology 2002; 22: 15-20.

6. Bolat F, Uslu S, Bülbül A. Yenidoğan ünitemizde indirekt hiperbilirubinemi tanısı ile yatırılan term yenidoğan bebeklerin değerlendirilmesi. Çocuk Dergisi 2010; 9: 69-74.

7. Grupp-Phelan J, Taylor JA, Liu LL, Davis RL. Early newborn hospital discharge and readmission for mild and severe jaundice. Arch Pediatr Adolesc Med 1999; 153: 1283-8.

8. Bülbül A, Okan F, Uslu S. Term bebeklerde klinik özellikleri ve risk etmenlerinin araştırılması. Türk Pediatri Arşivi 2005; 40: 204-10.

9. Maisels M, Kring E. Length of stay, jaundice, and hospital readmission. Pediatrics 1998; 101; 995-8.

10. Dubowitz LM, Dubowitz V, Palmer P, Verghote M. A new approach to the neurological assessment of the preterm and fullterm newborn infant. Brain Dev 1980; 2: 3-14.

11. Bernstein H, Spino C, Finch S. Decision making for postpartum discharge of 4300 mothers and their healthy infants: the life around newborn discharge study. Pediatrics 2007; 120: e391. nan bebeklerin daha erken kontrole çağırılarak yakın takibe alındı̆̆ını göstermektedir.

Sonuç olarak, indirekt hiperbilirubinemi nedeniyle yatışı yapılan yenidoğanlar, günümüzde halen yenidoğan ünitelerine yatırılan hastaların büyük bir kısmını oluşturmaktadır. Erken ve çok erken taburcuğun tekrar hastaneye yatışı arttırmadaki rolleriyle ilgili endişeler devam etmektedir. Çalışmamızda taburculuk saatinin geliş hiperbilirubinemi düzeyine etkisiz olduğunu saptadık. ABO uygunsuzluğunu, patolojik tartı kaybını ve taburculuk öncesi sarılık varlığını hiperbilirubinemi gelişimi açısından önemli risk faktörleri olarak belirledik.

12. Lock M, Ray JG. Higher neonatal morbidity after routine early hospital discharge: are we sending newborns home too early? Canadian Medical Association Journal 1999; 161: 249-53.

13. Kotagal UR, Atherton HD, Eshett R, Schoettker PJ, Perlstein PH. Safety of early discharge for Medicaid newborns. JAMA 1999; 282: 1150-6.

14. Polat A, Öktem F, Koç H. Yenidoğan hiperbilirubinemili 963 hastanın değerlendirilmesi, Türkiye Klinikleri Pediatri 1993; 2: 26-30.

15. Chou SC, Palmer RH, Ezhuthachan S, Newman C, PradellBoyd B, Maisels MJ, et al. Management of hyperbilirubinemia in newborns: measuring performance by using a benchmarking model. Pediatrics 2003; 112: 1264-73.

16. Katar S DC, Özel K, Sucaklı I. Kan değişimi yapılan yenidoğan bebeklerde hperbilirubinemi etiyolojisinin değerlendirilmesi. Dicle Tıp Dergisi 2006; 33: 174-7.

17. Sgro M, Campbell D, Shah V. Incidence and causes of severe neonatal hyperbilirubinemia in Canada. CMAJ 2006; 175: 58790.

18. Bertini G, Dani C, Tronchin M, Rubaltelli FF. Is breastfeeding really favoring early neonatal jaundice? Pediatrics 2001; 107: e41.

19. Osborn LM, Reiff MI, Bolus R. Jaundice in the full-term neonate. Pediatrics 1984; 73: 520-5.

20. Sgro M, Campbell D, Shah V. Incidence and causes of severe neonatal hyperbilirubinemia in Canada. CMAJ 2006; 175: 58790.

21. Yiğ̈it Ö, Sezgin B, Özgürhan G, Cambaz N. Indirekt hiperbilirubinemili olguların değerlendirilmesi. Bakırköy Tıp Dergisi 2006; 2: 41-6.

22. Ünal S, Eker $S$, Indirekt hiperbilirubinemili yenidoğanların geriye dönük olarak değerlendirilmesi. Türkiye Klinikleri J Pediatr 2008; 17: 223-9. 